\title{
Numerical Taxonomy of Moderately Halophilic Gram-negative Rods
}

\author{
By ANTONIO VENTOSA, ${ }^{1}$ EMILIA QUESADA, ${ }^{1}$ FRANCISCO \\ RODRIGUEZ-VALERA, ${ }^{2} \dagger$ FRANCISCO RUIZ-BERRAQUERO ${ }^{3}$ AND \\ ALBERTO RAMOS-CORMENZANA ${ }^{1 *}$ \\ ${ }^{1}$ Department of Microbiology, Faculty of Pharmacy, University of Granada, Granada, Spain \\ ${ }^{2}$ Department of Microbiology, University of Alicante, Alicante, Spain \\ ${ }^{3}$ Department of Microbiology, Faculty of Pharmacy, University of Sevilla, Sevilla, Spain
}

(Received 6 January 1982)

\begin{abstract}
A study was made of 516 randomly selected isolates of moderately halophilic bacteria from solar salterns showing salinities between 8.8 and $40.0 \%(\mathrm{w} / \mathrm{v})$ total salts, located in S.E. Spain. After purification, many cytological, physiological, biochemical, nutritional and antibiotic sensitivity characters were determined for 106 selected saltern isolates and two reference strains. Data were coded and analysed by numerical techniques using the Jaccard coefficient $\left(S_{J}\right)$, and clusters of strains were obtained by average linkage (UPGMA) analysis. Nine major phenons were found at the $72.5 \%$ similarity level. The properties of each phenon are given, their taxonomic affinities are discussed, and typical reference strains are suggested. Almost all the strains were related to genera known to contain marine species. A large number of the strains could be tentatively assigned to the genus Vibrio, suggesting that this may be an abundant taxon of moderately halophilic Gram-negative rods in solar salterns.
\end{abstract}

\section{INTRODUCTION}

The moderately halophilic bacteria are a heterogeneous group of micro-organisms characterized by growth over a wide range of salt concentrations. This range is difficult to define, because of its variability, depending on growth conditions (temperature and nutrients). However, these organisms are generally defined as bacteria showing optimum growth at concentrations between 0.5 and $2.5 \mathrm{M}-\mathrm{NaCl}$ (Kushner, 1978). Thus they have adapted to growth in hypersaline environments with salt concentrations higher than seawater, which differentiates them from normal marine or halotolerant bacteria. In spite of the recognized complex taxonomic composition of this group of bacteria (Larsen, 1962; Kushner, 1978), very few moderate halophiles have been adequately described from a taxonomic point of view. In the 8th edition of Bergey's Manual of Determinative Bacteriology (Buchanan \& Gibbons, '1974) only a few species are described as moderate halophiles. Furthermore, most of these have been isolated from salted food and the Dead Sea, two rather specialized hypersaline environments. Hypersaline waters derived from the concentration of seawater by evaporation are widespread throughout the world, and they probably represent the natural habitat of halophilic bacteria (Brock, 1979).

In a previous study, we studied the populations of heterotrophic bacteria in seawater evaporation ponds with concentrations between $10 \%(\mathrm{w} / \mathrm{v})$ total salts and $\mathrm{NaCl}$ saturation, and concluded that in ponds having concentrations up to $25 \%(\mathrm{w} / \mathrm{v})$ total salts, the predominant microorganisms were moderately halophilic Gram-negative rods (Rodriguez-Valera et al., 1981). In this paper, we present a numerical taxonomic study of a wide selection of these organisms isolated from solar salterns. The two species of moderately halophilic Gram-negative rods recognized in the Approved Lists of Bacterial Names (Skerman et al., 1980), viz. Vibrio costicola and Flavobacterium halmephilum, were included as reference strains.

$\dagger$ Present address: Department of Microbiology, Faculty of Pharmacy, University of Sevilla, Sevilla, Spain. 


\section{METHODS}

Sample collection and bacterial isolation. Samples were collected from the water of ponds of a commercial solar saltern near Alicante, S.E. Spain, between February 1979 and January 1980 . These ponds are $30 \mathrm{~cm}$ deep and have an average surface area of $20000 \mathrm{~m}^{2}$; their salt concentration is maintained approximately constant by means of an artificially regulated flow which runs from the less to the more concentrated ponds so that in each pond evaporation balances the entrance of less concentrated salt water. The diagram of the saltern in Fig. 1 shows the direction of the general flow of seawater and the salt concentration in some of the ponds during a sampling in summer 1979.

Samples were collected from a depth of $10 \mathrm{~cm}$ at the edge of the ponds in sterile plastic tubes, and were plated as soon as possible (not more than $12 \mathrm{~h}$ after collection). The samples were kept at room temperature during this interval. The medium used for isolation was as follows $(\%, \mathrm{w} / \mathrm{v}): \mathrm{NaCl}, 17 \cdot 8 ; \mathrm{MgSO}_{4} .7 \mathrm{H}_{2} \mathrm{O}, 0 \cdot 1 ; \mathrm{CaCl}_{2} .2 \mathrm{H}_{2} \mathrm{O}$, $0.036 ; \mathrm{KCl}, 0.2 ; \mathrm{NaHCO}_{3}, 0.006 ; \mathrm{NaBr}, 0.023 ; \mathrm{FeCl}_{3} .6 \mathrm{H}_{2} \mathrm{O}$, trace; Proteose-peptone no. 3 (Difco), $0.5 ;$ yeast extract (Difco), 1.0; glucose, $0 \cdot 1$; Bacto-agar (Difco), $2 \cdot 0 ; \mathrm{pH} 7 \cdot 2$ adjusted with $\mathrm{KOH}$. This medium (designated $\mathrm{HM}$ ) is very selective for moderate halophiles because of its low $\mathbf{M g}^{2+}$ content, which does not support good growth of extreme halophiles. The samples were surface-inoculated on HM medium either directly or diluted in sterile $\mathrm{HM}$ salts solution and incubated at $35^{\circ} \mathrm{C}$ for $7-10 \mathrm{~d}$ in sealed plastic bags. Colonies were isolated at random up to a total of 516, and successively subcultured on $\mathrm{HM}$ to ensure purity. The Gram reaction and the salt response of the strains were determined. Among the Gram-negative rods that showed a moderately halophilic salt response, 106 strains were randomly selected for numerical taxonomic analysis, and studied together with two bacteria from culture collections: Vibrio costicola NCMB 701 and Flavobacterium halmephilum CCM 2833. The salt concentrations of the ponds from which the strains used for numerical taxonomy were derived were between $8 \cdot 8$ and $40 \cdot 0 \%$ $(\mathrm{w} / \mathrm{v})$ total salts.

The strains were maintained on agar slants with $10 \%(\mathrm{w} / \mathrm{v})$ marine salts $(\%, \mathrm{w} / \mathrm{v}): \mathrm{NaCl}, 8 \cdot 1 ; \mathrm{MgCl}_{2}, 0 \cdot 7$; $\mathrm{MgSO}_{4}, 0.96 ; \mathrm{CaCl}_{2}, 0.036 ; \mathrm{KCl}, 0.2 ; \mathrm{NaHCO}_{3}, 0.006 ; \mathrm{NaBr}, 0.0026$ (Rodriguez-Valera et al., 1980) supplemented with $0.5 \%(w / v)$ Proteose-peptone no. $3(\mathrm{Difco}), 1 \%(\mathrm{w} / \mathrm{v})$ yeast extract (Difco) and $0 \cdot 1 \%(\mathrm{w} / \mathrm{v})$ glucose.

Characterization of isolates. For each strain 117 phenotypic characteristics were determined. Unless otherwise indicated, incubation was at $35^{\circ} \mathrm{C}$ and the $\mathrm{pH}$ of all media was adjusted to 7.0 with $\mathrm{KOH}$ and contained $10 \%(\mathrm{w} / \mathrm{v})$ marine salts as above.

Morphology. Gram staining was done according to Dussault (1955). Motility was determined in wet mounts. Flagella were stained by the technique of Rhodes (1958). Colony morphology and size, and production of diffusible and non-diffusible pigments, were examined on HM medium after $5 \mathrm{~d}$ incubation.

Physiological and biochemical tests. Growth at different salt concentrations was determined on solid medium with total marine salts at $0 \cdot 5,2,5,10,15,20$ or $25 \%(w / v)$. These media were supplemented with nutrients as in the maintenance medium. The concentration in which growth appeared first was considered optimal; growth was considered positive when it was visible after $15 \mathrm{~d}$ incubation. The $\mathrm{pH}$ range of growth was determined in a similar way on media in which the $\mathrm{pH}$ was adjusted to $5 \cdot 0,6 \cdot 0,7 \cdot 0,8 \cdot 0,9 \cdot 0$ or 10.0 with $\mathrm{HCl}$ or $\mathrm{KOH}$. The pH was readjusted after sterilization. Temperature range was determined as above by incubation at $5,15,25,35$ or $45^{\circ} \mathrm{C}$. The result was considered positive if there was visible growth after $7 \mathrm{~d}$, except for $5^{\circ} \mathrm{C}$, at which the incubation time was 3 weeks. The ability to grow anaerobically was evaluated on streaked plates of the same medium incubated in jars with the GasPak Anaerobic System (BBL). The appearance of growth was checked after $15 \mathrm{~d}$ incubation.

Cultures grown for $24 \mathrm{~h}$ on the maintenance medium were tested for catalase [with $3 \%(\mathrm{w} / \mathrm{v}) \mathrm{H}_{2} \mathrm{O}_{2}$ ] and cytochrome oxidase production (Kovacs, 1956). Acid production from glucose, sucrose, lactose, mannitol, inositol, maltose and galactose was detected in the basal medium: $10 \%(\mathrm{w} / \mathrm{v})$ marine salts, $1 \%(\mathrm{w} / \mathrm{v})$ Peptone P (Oxoid), $0.5 \%(\mathrm{w} / \mathrm{v})$ yeast extract (Difco) and $0.001 \%(\mathrm{w} / \mathrm{v})$ phenol red. Carbohydrates were sterilized by filtration and added to the previously autoclaved basal medium at a final concentration of $1 \%(\mathrm{w} / \mathrm{v})$. Inverted Durham tubes were used to visualize gas production. The utilization of glucose by oxidation or fermentation was checked in a modified MOF medium (Leifson, 1963), of the following composition ( $\%$, w/v): $\mathrm{NaCl}, 10 ; \mathrm{MgSO}_{4} \cdot 7 \mathrm{H}_{2} \mathrm{O}, 0 \cdot 2$; $\mathrm{KCl}, 0 \cdot 2 ; \mathrm{CaCl}_{2} .2 \mathrm{H}_{2} \mathrm{O}, 0.05 ; \mathrm{FeCl}_{3} .6 \mathrm{H}_{2} \mathrm{O}$, trace; $\left(\mathrm{NH}_{4}\right)_{2} \mathrm{SO}_{4}, 0.05$; Tris buffer, 0.05 ; Peptone $\mathrm{P}(\mathrm{Oxoid}), 0 \cdot 1$; yeast extract (Difco), 0.01; Bacto-agar (Difco), $0.3 ;$ phenol red, $0.001 ; 1 \%(w / v)$ filter-sterilized glucose was added to the previously autoclaved medium.

$\mathrm{H}_{2} \mathrm{~S}$ production was tested in the maintenance medium containing $0.01 \%(w / v)$ cysteine, with a strip of lead acetate-impregnated paper in the mouth of the tubes as indicator. For the nitrate reduction test the maintenance medium was supplemented with $0 \cdot 2 \%(\mathrm{w} / \mathrm{v}) \mathrm{KNO}_{3}$. Nitrite was detected with naphthylamine/sulphanilic acid reagents and residual nitrate with zinc dust; production of $\mathrm{N}_{2}$ was detected in inverted Durham tubes (Skerman, 1967).

Gelatin hydrolysis was tested by flooding cultures on the maintenance medium containing $1 \%(\mathrm{w} / \mathrm{v})$ gelatin with the Frazier reagent (Frazier, 1926) and also solidifying the medium with $15 \%(\mathrm{w} / \mathrm{v})$ gelatin and stab inoculating the tubes; liquefaction after $7 \mathrm{~d}$ at $22{ }^{\circ} \mathrm{C}$ was considered positive. Casein hydrolysis was tested on plates made by 


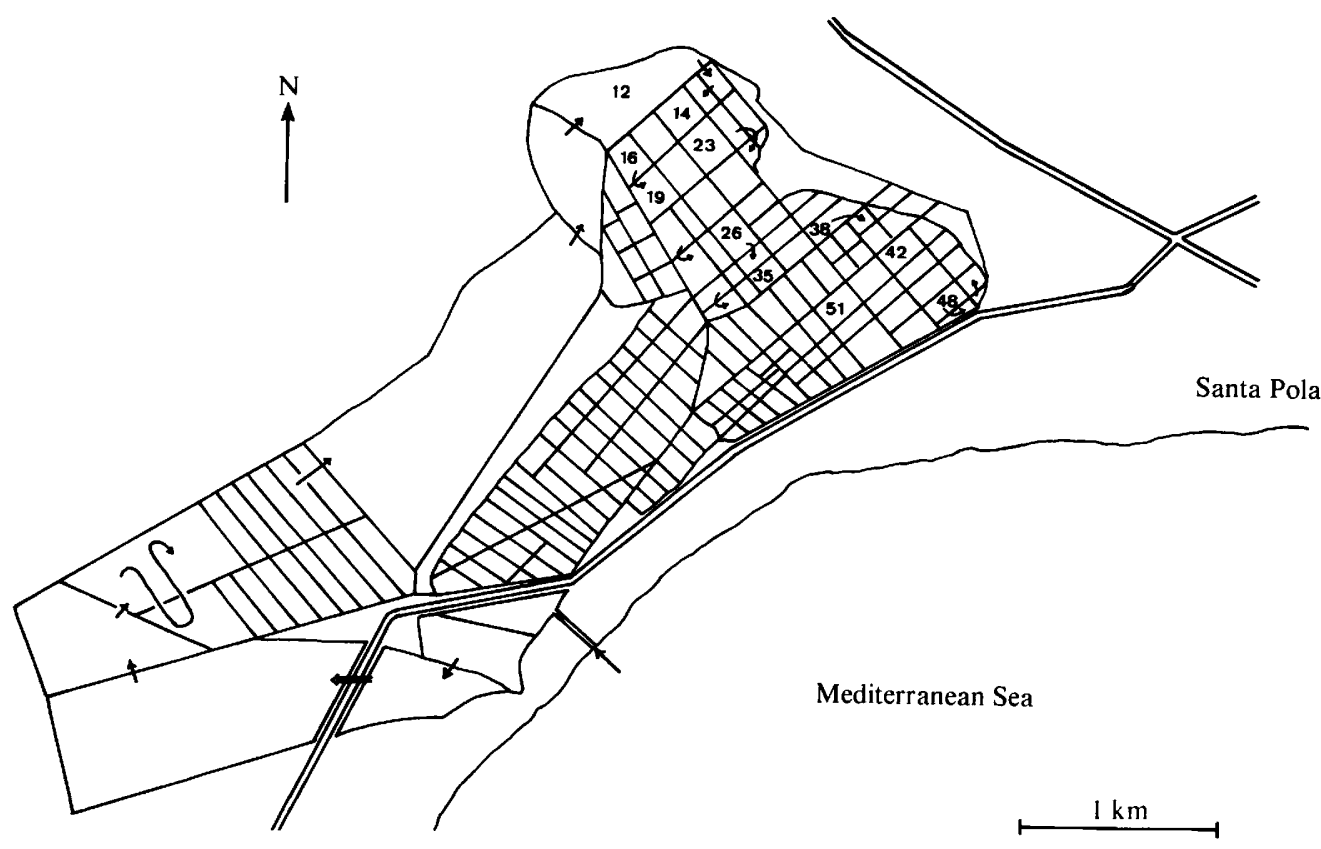

Fig. 1. Diagram of the saltern used for this study. Numbers in the ponds indicate the salt concentration $(\%, w / v)$ during the summer of 1979 . The arrows indicate the direction of flow of seawater from the Mediterranean Sea.

mixing double-strength maintenance medium with an equal amount of skim milk (Cowan \& Steel, 1974). Starch hydrolysis was tested by flooding with Lugol's iodine plate cultures on the maintenance medium containing $1 \%$ (w/v) potato starch. Lipase activity was detected on a modified Sierra medium (Sierra, 1957) with the following composition $\left(\%\right.$, w/v): $\mathrm{NaCl}, 9 \cdot 6 ; \mathrm{KCl}, 0 \cdot 2 ; \mathrm{MgSO}_{4} .7 \mathrm{H}_{2} \mathrm{O}, 0.2 ; \mathrm{CaCl}_{2} .2 \mathrm{H}_{2} \mathrm{O}, 0 \cdot 02 ; \mathrm{FeCl}_{3} .6 \mathrm{H}_{2} \mathrm{O}$, trace; Peptone $\mathrm{P}$ (Oxoid), 1.0; yeast extract (Difco), 0.5; Bacto-agar (Difco), 2-0. The sterilized medium was supplemented with $1 \%(\mathrm{w} / \mathrm{v})$ of separately autoclaved Tween 20,60 or 80 (Merck). Urea hydrolysis was detected in the medium of Christensen (1946) to which the salts of the maintenance medium were added. Indole production was tested in liquid maintenance medium; the presence of indole was shown with the Kovacs reagent (Kovacs, 1928). Methyl red and Voges-Proskauer tests were done in a medium as follows $(\%, w / v): \mathrm{NaCl}, 9 \cdot 8 ; \mathrm{KCl}, 0 \cdot 2 ; \mathrm{MgSO}_{4} .7 \mathrm{H}_{2} \mathrm{O}$, $0.02 ; \mathrm{FeCl}_{3} \cdot 6 \mathrm{H}_{2} \mathrm{O}$, trace; $\mathrm{K}_{2} \mathrm{HPO}_{4}, 0 \cdot 5 ;$ Peptone $\mathrm{P}$ (Oxoid), $0 \cdot 5$; yeast extract (Difco), $0 \cdot 25 ;$ glucose, $0 \cdot 5$. DNAase activity was tested by the method of Jeffries et al. (1957) on DNAase agar (Oxoid) prepared with $10 \%$ (w/v) marine salts solution.

Nutritional tests. The basal medium was as follows $\left(\%\right.$ w/v): $\mathrm{NaCl}, 10 \cdot 0 ; \mathrm{KCl}, 0 \cdot 2 ; \mathrm{MgSO}_{4} \cdot 7 \mathrm{H}_{2} \mathrm{O}, 0.02 ; \mathrm{KNO}_{3}$, $0 \cdot 1 ;\left(\mathrm{NH}_{4}\right)_{2} \mathrm{HPO}_{4}, 0 \cdot 1 ; \mathrm{KH}_{2} \mathrm{PO}_{4}, 0.05$. To this liquid medium a $0 \cdot 1 \%(\mathrm{w} / \mathrm{v})$ filter-sterilized substrate was added. Carbohydrates were used at a final concentration of $0.2 \%(\mathrm{w} / \mathrm{v})$. When amino acids were used as substrate the basal medium contained neither $\mathrm{KNO}_{3}$ nor $\left(\mathrm{NH}_{4}\right)_{2} \mathrm{HPO}_{4}$. The organic compounds used as sole source of carbon and energy, or carbon and nitrogen and energy were: aesculin, L-arabinose, cellobiose, D-fructose, D-galactose, Dglucose, inulin, lactose, maltose, D-mannose, raffinose, L-rhamnose, salicin, L-sorbose, starch, sucrose, trehalose, D-xylose, adonitol, dulcitol, glycerol, meso-inositol, D-mannitol, D-sorbitol, acetate, aspartate, benzoate, caprylate, citrate, formate, fumarate, gluconate, hippurate, lactate, malate, oxalate, propionate, pyruvate, succinate, Dtartrate, L-alanine, L-arginine, L-asparagine, L-cysteine, L-glutamic acid, L-histidine, L-isoleucine, L-leucine, Llysine, L-ornithine, L-serine, L-tryptophan, L-valine. Growth was scored visually; it was judged negative if turbidity was no greater than in a control tube of basal medium with no added organic compound, and positive if the turbidity was obviously greater than in the control tube. Doubtful results were checked by transferring a loopful to a fresh tube of the same medium. A repeatedly doubtful result was considered negative.

Antibiotic and vibriostat sensitivity tests. Antibiotic sensitivity was tested by spreading bacterial suspensions on plates of maintenance medium and applying BBL antibiotic discs (bacitracin, 10 units; cephalothin, $30 \mu \mathrm{g}$; chloramphenicol, $30 \mu \mathrm{g}$; erythromycin, $15 \mu \mathrm{g}$; neomycin, $30 \mu \mathrm{g}$; novobiocin, $30 \mu \mathrm{g}$; penicillin $\mathrm{G}, 10$ units; polymyxin B, 300 units; rifampin, $5 \mu \mathrm{g}$; streptomycin, $10 \mu \mathrm{g}$; tetracycline, $30 \mu \mathrm{g}$ ). Zones of inhibition were measured and sensitivity was determined against standard inhibition zones (BBL). Sensitivity to the vibriostatic 
agent pteridine 0/129 (Sigma) was tested using discs prepared according to Bain \& Shewan (1968). In the interpretation of the results of these tests the salt effect must be considered, since it has been shown that some of these agents can be inactivated by high salt concentrations e.g. pteridine 0/129 (Merkel, 1972).

Numerical analysis. Taxonomic characters were coded in two-state binary form. Similarities were estimated with the Jaccard coefficient $\left(S_{J}\right)$ (Jaccard, 1908) and cluster analysis was done by the unweighted pair-group method of association (UPGMA) (Sneath \& Sokal, 1973). These computations were done with the MINT program of Dr F. J. Rolf of the Department of Ecology and Evolution, State University of New York at Stony Brook, New York, U.S.A., adapted by him for the NCR computer of the Gulbenkian Institute of Sciences, Oeiras, Portugal.

\section{RESULTS AND DISCUSSION}

\section{Halophilic character of the isolates}

Of the 516 strains isolated, most (481) were moderately halophilic. Almost without exception they grew optimally at $10 \%(\mathrm{w} / \mathrm{v})$ total salts. The rest of the isolates were halotolerant and grew better without added salts. The range of growth of the moderate halophiles at different salt concentrations varied: $49.5 \%$ of them grew with between 2 and $25 \%(\mathrm{w} / \mathrm{v})$ total salts in the medium, $34.1 \%$ grew with between 2 and $20 \%$ (w/v), and the remaining $16.4 \%$ with between 5 and $25 \%(\mathrm{w} / \mathrm{v})$. These ranges are somewhat wider than those previously reported (Larsen, 1962; Kushner, 1978). We have observed a tendency for the range of salt tolerance to diminish during successive subculture of the strains in laboratory media.

A total of 106 strains were finally selected, together with Vibrio costicola NCMB 701 and Flavobacterium halmephilum CCM 2833, for numerical analysis; all were moderately halophilic Gram-negative rods.

\section{Numerical analysis}

The results of the numerical study of the selected strains using the $S_{J}$ coefficient, clustered by the unweighted average linkage method, gave the dendrogram shown in Fig. 2. Nine phenons containing three or more strains were defined at $72.5 \%$ similarity; 17 strains did not cluster at this similarity level.

Two major groups of phenons were observed which corresponded, respectively, to nonfermentative (phenons A, B, C, D and E) and fermentative strains (phenons F, G, H and I). The features of the nine phenons are shown in Table 1. Simple matching $\left(S_{S M}\right)$ coefficient and single linkage clustering were also used, but the cluster composition was not markedly affected. The estimated test error was less than $3.5 \%$, which would not significantly affect the cluster analysis.

Phenon $A$. The 18 strains included in this group were clustered at a $73 \%$ similarity level. They were yellow-pigmented, motile, straight rods, peritrichously flagellated, and strictly aerobic, catalase positive, oxidase negative, and $\mathrm{H}_{2} \mathrm{~S}$ producers (except one strain, A-9). They were not proteolytic and were unable to reduce either nitrate or nitrite. Carbohydrates were used oxidatively. One marked characteristic of strains in this group was their ability to utilize a large number of organic compounds as sole sources of carbon and energy.

According to the 8th edition of Bergey's Manual of Determinative Bacteriology (Buchanan \& Gibbons, 1974), phenon A could be classified in Section 2 of the genus Flavobacterium. However, the only moderately halophilic species described in this genus is Flavobacterium halmephilum, and there were physiological, biochemical and nutritional differences between this and our isolates. Nor was this cluster similar to any of the other marine species of Flavobacterium described by Weeks in Bergey's Manual of Determinative Bacteriology (Buchanan \& Gibbons, 1974). Recently Holmes \& Owen (1979) proposed an emended description of Flavobacterium, according to which phenon $A$, as well as the other species presently included in Section 2 would not be included in this genus.

Phenon $B$. This was composed of seven strains, clustered at a similarity level of $87 \%$. This was a homogeneous group, characterized by the possession of two pigments, a yellow carotenoid and a violet pigment that was not violacein. These micro-organisms were straight rods, motile by peritrichous flagella, strict aerobes, catalase positive and oxidase negative. They utilized carbohydrates oxidatively producing acids but not gas. Nitrate but not nitrite was reduced. Neither 
Percentage similarity

No. of strains/

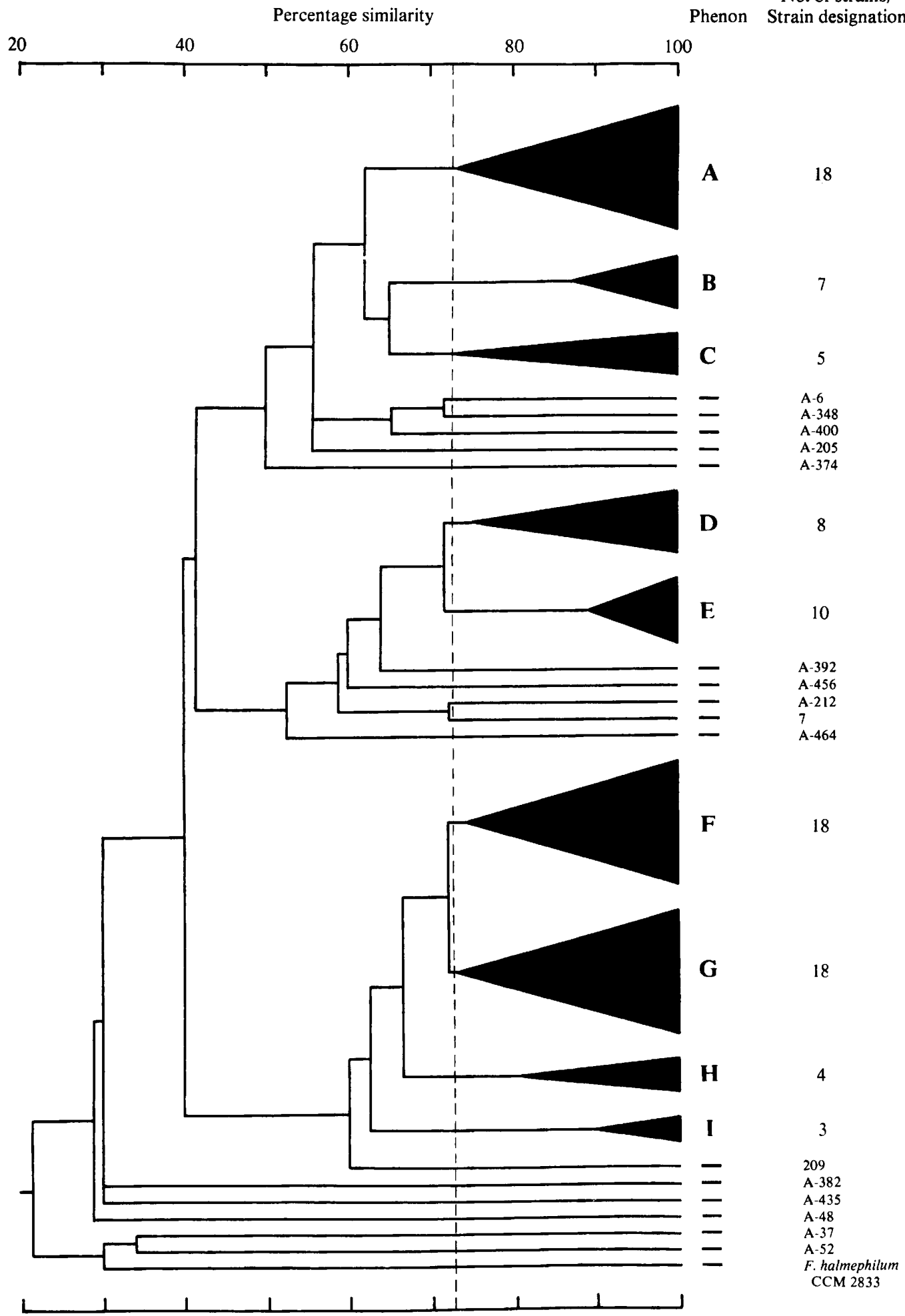

Fig. 2. Simplified dendrogram showing the clustering of strains into 9 phenons based on the $S_{J}$ coefficient and unweighted average linkage clustering (UPGMA), for 108 moderately halophilic Gram-negative bacteria. 
Table 1. Frequencies of positive characters found in the phenons

Frequencies are expressed as a percentage of the total scored in each group for the given test.

$\begin{array}{rccccccccc}\text { Phenon ... } & \text { A } & \text { B } & \text { C } & \text { D } & \text { E } & \text { F } & \text { G } & \text { H } & \text { I } \\ \text { No. of strains ... } & 18 & 7 & 5 & 8 & 10 & 18 & 18 & 4 & 3\end{array}$

\begin{tabular}{|c|c|c|c|c|c|c|c|c|c|}
\hline \multicolumn{10}{|l|}{ Morph } \\
\hline Straight rods & 100 & 100 & 100 & 100 & 100 & 11 & 17 & 25 & 0 \\
\hline Curved axis & 0 & 0 & 0 & 0 & 0 & 89 & 83 & 75 & 100 \\
\hline \multicolumn{10}{|l|}{ Colony pigment } \\
\hline Yellow & 100 & 100 & 100 & 0 & 10 & 0 & 6 & 0 & 0 \\
\hline Cream & 0 & 0 & 0 & 100 & 90 & 94 & 94 & 100 & 100 \\
\hline Violet & 0 & 100 & 0 & 0 & 0 & 0 & 0 & 0 & 0 \\
\hline White & 0 & 0 & 0 & 0 & 0 & 6 & 0 & 0 & 0 \\
\hline \multicolumn{10}{|l|}{ Flagella } \\
\hline Polar & 0 & 0 & 0 & 100 & 20 & 100 & 100 & 100 & 100 \\
\hline Peritrichous & 100 & 100 & 100 & 0 & 80 & 0 & 0 & 0 & 0 \\
\hline \multicolumn{10}{|l|}{ Salts: growth at } \\
\hline $2 \%(w / v)$ & 100 & 100 & 100 & 87 & 100 & 100 & 100 & 100 & 100 \\
\hline $25 \%(\mathrm{w} / \mathrm{v})$ & 94 & 100 & 100 & 50 & 90 & 11 & 28 & 25 & 0 \\
\hline \multicolumn{10}{|l|}{$\mathrm{pH}$ : growth at } \\
\hline pH 5 & 11 & 100 & 100 & 0 & 0 & 0 & 0 & 0 & 0 \\
\hline pH 10 & 100 & 100 & 80 & 100 & 100 & 89 & 72 & $\mathbf{0}$ & 33 \\
\hline \multicolumn{10}{|l|}{ Temperature: growth at } \\
\hline $5{ }^{\circ} \mathrm{C}$ & 56 & 0 & 0 & 0 & 0 & 33 & 22 & 0 & $\mathbf{0}$ \\
\hline $45^{\circ} \mathrm{C}$ & 0 & 100 & 0 & 100 & 100 & 22 & 22 & 0 & $\mathbf{0}$ \\
\hline Anaerobic growth & 0 & 0 & 0 & 0 & $\mathbf{0}$ & 100 & 100 & 100 & 100 \\
\hline \multicolumn{10}{|l|}{ Acid production from } \\
\hline Galactose & 100 & 100 & 100 & 0 & 0 & 100 & 100 & 100 & 66 \\
\hline Glucose (oxidative) & 100 & 100 & 100 & 50 & 100 & 0 & 0 & $\mathbf{0}$ & 0 \\
\hline Glucose (fermentative) & 0 & 0 & 0 & 0 & 0 & 100 & 100 & 100 & 100 \\
\hline Inositol & 0 & 29 & 0 & 0 & 0 & 94 & 100 & 100 & 66 \\
\hline Lactose & 0 & 100 & 60 & 12 & 0 & 100 & 94 & 100 & 66 \\
\hline Maltose & 28 & 71 & 0 & 0 & 10 & 100 & 100 & 100 & 100 \\
\hline Mannitol & 0 & 29 & 0 & 0 & 0 & 100 & 100 & 100 & 66 \\
\hline Sucrose & 22 & 100 & 0 & 0 & 30 & 100 & 100 & 100 & 100 \\
\hline Oxidase & 0 & 0 & 0 & 100 & 100 & 100 & 100 & 100 & 100 \\
\hline $\mathrm{H}_{2} \mathrm{~S}$ production & 94 & 57 & 60 & 0 & 0 & 94 & 100 & 100 & 100 \\
\hline Nitrate reductior & 11 & 100 & 0 & 100 & 100 & 0 & 0 & 0 & 0 \\
\hline Nitrite reduction to nitrogen & 0 & 0 & 0 & 100 & 100 & 0 & 0 & 0 & 0 \\
\hline Gelatin hydrolysis & 0 & 0 & 0 & 0 & 0 & 100 & 100 & 100 & 100 \\
\hline Casein hydrolysis & 0 & 0 & 0 & 0 & 0 & 94 & 100 & 100 & 100 \\
\hline Starch hydrolysis & 0 & 0 & 0 & 0 & 0 & 0 & 6 & $\mathbf{0}$ & 0 \\
\hline Tween 20 hydrolysis & 22 & 0 & 0 & 12 & 0 & 0 & 100 & 100 & 100 \\
\hline Tween 60 hydrolysis & 22 & $\mathbf{0}$ & 0 & 12 & $\mathbf{0}$ & 0 & 100 & 100 & 100 \\
\hline Tween 80 hydrolysis & 22 & 0 & 0 & 12 & 0 & 0 & 100 & 100 & 100 \\
\hline Indole production & 0 & 0 & 0 & 0 & 0 & 6 & 6 & 0 & 0 \\
\hline Methyl red & 0 & $\mathbf{0}$ & 0 & 0 & 0 & 78 & 56 & 100 & 66 \\
\hline Voges-Proskauer & 0 & 0 & 0 & 0 & 0 & 100 & 100 & 100 & 100 \\
\hline DNAase & 0 & 0 & 0 & 0 & 0 & 100 & 100 & 100 & 100 \\
\hline
\end{tabular}

compounds as sole source

of carbon and energy:

Carbohydrates

Aesculin
L-Arabinose
Cellobiose
D-Fructose
D-Galactose
Maltose
D-Mannose
L-Rhamnose
Salicin
L-Sorbose
Starch

$\begin{array}{rrr}72 & 0 & 0 \\ 100 & 100 & 100 \\ 89 & 0 & 20 \\ 100 & 100 & 100 \\ 100 & 100 & 100 \\ 100 & 100 & 20 \\ 100 & 100 & 100 \\ 0 & 57 & 40 \\ 72 & 0 & 0 \\ 28 & 100 & 20 \\ 0 & 0 & 0\end{array}$

$\begin{array}{rrrrr}10 & 11 & 6 & 0 & 0 \\ 0 & 0 & 0 & 0 & 0 \\ 0 & 28 & 0 & 0 & 0 \\ 80 & 100 & 100 & 100 & 100 \\ 0 & 44 & 0 & 100 & 33 \\ 100 & 89 & 100 & 75 & 33 \\ 100 & 17 & 44 & 50 & 66 \\ 0 & 0 & 0 & 0 & 0 \\ 0 & 6 & 11 & 100 & 0 \\ 0 & 6 & 6 & 0 & 0 \\ 0 & 89 & 83 & 100 & 100\end{array}$


Table 1 (continued)

\begin{tabular}{|c|c|c|c|c|c|c|c|c|c|}
\hline $\begin{array}{r}\text { Phenon } \ldots \\
\text { No. of strains } \ldots\end{array}$ & $\begin{array}{c}\mathrm{A} \\
18\end{array}$ & $\begin{array}{l}\text { B } \\
7\end{array}$ & $\begin{array}{l}C \\
5\end{array}$ & $\begin{array}{l}\text { D } \\
8\end{array}$ & $\begin{array}{c}\mathrm{E} \\
10\end{array}$ & $\begin{array}{l}\mathrm{F} \\
18\end{array}$ & $\begin{array}{l}\mathrm{G} \\
18\end{array}$ & $\begin{array}{c}\mathrm{H} \\
4\end{array}$ & $\begin{array}{l}\text { I } \\
3\end{array}$ \\
\hline Sucrose & 100 & 100 & 20 & 0 & 100 & 72 & 89 & 0 & 33 \\
\hline Trehalose & 100 & 57 & 0 & 0 & 100 & 94 & 100 & 75 & 33 \\
\hline Xylose & 78 & 100 & 80 & 0 & 0 & 22 & 0 & 0 & 0 \\
\hline \multicolumn{10}{|l|}{ Alcohols } \\
\hline Adonitol & 39 & 100 & 0 & 0 & 0 & 0 & 0 & 0 & . \\
\hline Dulcitol & 17 & 100 & 100 & 0 & 0 & 0 & 0 & 0 & 0 \\
\hline Glycerol & 100 & 100 & 100 & 87 & 100 & 100 & 94 & 100 & 100 \\
\hline meso-Inositol & 94 & 100 & 0 & 12 & 0 & 6 & 0 & 100 & 0 \\
\hline D-Mannitol & 100 & 100 & 100 & 0 & 0 & 50 & 33 & 25 & 100 \\
\hline D-Sorbitol & 94 & 100 & 100 & 0 & 0 & 22 & 28 & 100 & 0 \\
\hline \multicolumn{10}{|l|}{ Carboxylic acids } \\
\hline Aspartate & 94 & 100 & 100 & 100 & 100 & 83 & 100 & 100 & 33 \\
\hline Benzoate & 11 & 100 & 0 & 0 & 0 & 0 & 0 & 0 & 0 \\
\hline Citrate & 100 & 100 & 100 & 100 & 100 & 22 & 28 & 100 & 0 \\
\hline Fumarate & 100 & 100 & 100 & 100 & 100 & 100 & 100 & 100 & 66 \\
\hline Gluconate & 100 & 100 & 100 & 75 & 100 & 89 & 78 & 100 & 0 \\
\hline Propionate & 89 & 100 & 60 & 100 & 100 & 100 & 100 & 100 & 100 \\
\hline Succinate & 100 & 100 & 100 & 100 & 100 & 100 & 83 & 100 & 33 \\
\hline \multicolumn{10}{|l|}{$\begin{array}{l}\text { Utilization of amino acids } \\
\text { as sole source of carbon, } \\
\text { nitrogen and energy: }\end{array}$} \\
\hline L-Ärginine & 89 & 100 & 100 & 100 & 100 & 100 & 100 & 100 & 100 \\
\hline L-Asparagine & 100 & 100 & 100 & 100 & 100 & 94 & 100 & 100 & 100 \\
\hline L-Cysteine & 11 & 0 & 0 & 0 & 20 & 89 & 89 & 75 & 0 \\
\hline L-Glutamic acid & 100 & 57 & 80 & 100 & 100 & 100 & 100 & 100 & 100 \\
\hline L-Histidine & 0 & 0 & 20 & 100 & 100 & 94 & 83 & 25 & 33 \\
\hline L-Isoleucine & 44 & 0 & 0 & 100 & 100 & 0 & 0 & 0 & 0 \\
\hline L-Leucine & 56 & 0 & 0 & 100 & 100 & 0 & 0 & 0 & 0 \\
\hline L-Lysine & 33 & 100 & 40 & 100 & 100 & 0 & 0 & 0 & 0 \\
\hline L-Ornithine & 94 & 100 & 100 & 100 & 100 & 100 & 100 & 100 & 100 \\
\hline L-Serine & 72 & 100 & 40 & 100 & 100 & 100 & 100 & 100 & 100 \\
\hline L-Tryptophan & 0 & 0 & 0 & 100 & 100 & 0 & 0 & 0 & 0 \\
\hline L-Valine & 17 & 0 & 0 & 87 & 100 & 0 & 0 & 0 & 0 \\
\hline \multicolumn{10}{|l|}{$\begin{array}{l}\text { Antibiotic and vibriostatic } \\
\text { susceptibility: }\end{array}$} \\
\hline Bacitracin & 0 & 14 & 0 & 0 & 0 & 17 & 11 & 0 & 0 \\
\hline Cephalothin & 89 & 0 & 0 & 100 & 100 & 22 & 33 & 25 & 33 \\
\hline Chloramphenicol & 100 & 14 & 0 & 100 & 100 & 100 & 100 & 100 & 100 \\
\hline Erythromycin & 100 & 29 & 60 & 50 & 60 & 44 & 33 & 100 & 0 \\
\hline Neomycin & 22 & 71 & 40 & 0 & 10 & 0 & 0 & 0 & 0 \\
\hline Novobiocin & 0 & 0 & 0 & 0 & 20 & 100 & 83 & 100 & 66 \\
\hline Penicillin G & 89 & 14 & 40 & 50 & 80 & 50 & 78 & 100 & 33 \\
\hline Polymyxin B & 22 & 57 & 0 & 75 & 80 & 100 & 100 & 100 & 66 \\
\hline Rifampin & 72 & 0 & 0 & 37 & 40 & 17 & 6 & 0 & 0 \\
\hline
\end{tabular}

All strains were Gram-negative, motile, formed catalase, grew at 5, 10,15 or $20 \%(\mathrm{w} / \mathrm{v})$ total salts, grew at $\mathrm{pH} 6,7,8$, or 9 , grew at 15,25 , or $35^{\circ} \mathrm{C}$, and grew on D-glucose, acetate, lactate, malate or pyruvate as sole carbon sources or on L-alanine as sole carbon and nitrogen source. None hydrolysed urea, grew on inulin, lactose, raffinose, caprylate, formate, hippurate or oxalate as sole carbon sources, or were susceptible to streptomycin, tetracycline and vibriostat $0 / 129$.

proteolytic nor lipolytic activity was detected. The description of this group fits well with that for Chromobacterium maris-mortui, isolated by Elazari-Volcani (1940) from the Dead Sea. This species in the 8th edition of Bergey's Manual of Determinative Bacteriology (Buchanan \& Gibbons, 1974) appears as incertae sedis and was not included in the Approved Lists of Bacterial Names (Skerman et al., 1980). Because of the absence of violacein and the peritrichous flagellation of strains in this phenon, they cannot be included in the genus Chromobacterium as defined by most authors (Sneath, 1974). DNA :rRNA hybridization studies have shown Chromobacter- 
ium maris-mortui to be distinct from both Chromobacterium and Janthinobacterium (De Ley et al., 1978). This suggests the requirement for a new taxon to accommodate these micro-organisms. Investigations are in progress to define properly their taxonomic position.

Phenon $C$. This group of five strains was very similar to phenon A, from which they were distinguished by their lower metabolic versatility, utilizing a much narrower range of organic compounds. Tentatively, they can also be placed in the genus Flavobacterium.

Phenon $D$. The eight strains included in this phenon were straightor sometimes slightly curved rods. They were motile by polar flagella, strict aerobes, catalase and oxidase positive; they reduced nitrate and nitrite; no proteolytic or lipolytic activity was detected. They could be assigned to the genus Alteromonas, possibly in the species Alteromonas communis. The main differences were the salt requirements and the reduction of nitrate, which was positive in phenon D and negative in Alteromonas communis.

Phenon $E$. The 10 strains included in this phenon clustered at a similarity level of $89 \%$, and formed the most compact cluster recovered in this study. They formed pale yellow or creampigmented colonies, and were straight rods that sometimes produced highly elongated flexible forms. They were strict aerobes, catalase and oxidase positive; glucose was used oxidatively, nitrate and nitrite were reduced; $\mathrm{H}_{2} \mathrm{~S}$ was not produced, and no proteolytic or lipolytic activity was detected. Only a few sugars were used as sole carbon and energy sources but amino acids and organic acids were readily utilized. These strains could be assigned to the genus Alcaligenes. They conform to the description of the marine bacterium Alcaligenes venustus (Baumann et al., 1972), apart from the salt requirement.

Phenon $F$. This contained 18 strains related at a similarity level of $74 \%$. They were curved rods, motile by polar flagella, and sometimes formed spiral chains of several cells that had a peculiar corkscrew-like motility. They were facultatively anaerobic, catalase and oxidase positive. Metabolism of carbohydrates was fermentative; nitrate and nitrite were not reduced. They produced $\mathrm{H}_{2} \mathrm{~S}$ and DNAase, and were gelatinolytic and caseinolytic but not lipolytic.

According to the 8th edition of Bergey's Manual of Determinative Bacteriology (Buchanan \& Gibbons, 1974), this group clearly belongs to the family Vibrionaceae, and could be placed in the genus Vibrio. The reference strain Vibrio costicola NCMB 701 was recovered in this phenon. The main differences between Vibrio costicola NCMB 701 and our isolates was that the first is not proteolytic and reduces nitrates while our isolates were proteolytic and did not reduce nitrates.

Phenon $G$. This contained 18 strains related at a similarity level of $73 \%$. They were polarly flagellated curved rods with very similar characteristics to phenon $\mathrm{F}$, the main difference being their strong lipolytic activity, a feature absent in the previous group. They could also be assigned to Vibrio.

Phenons $H$ and $I$. The strains in these two clusters were curved rods very similar to the strains in the two previous phenons, and could also be classified in the genus Vibrio. They showed wider rutritional versatility than the strains in phenons $F$ and $G$.

\section{General discussion}

The differential characteristics of the nine phenons are summarized in Table 2, which also includes suggested reference strains for each phenon. It is hoped that others may be able to extend these studies by furnishing molecular and genetic data.

This is to our knowledge the first systematic study of the taxonomy of moderately halophilic bacteria from solar salterns, even though these probably constitute one of the more typical and representative hypersaline environments. The variety of taxonomic groups that we have found is much larger than the literature would suggest, and it seems that very different groups of bacteria have representatives that are moderately halophilic. Many of the micro-organisms included in this study cannot be classified in any previously defined taxonomic scheme, a situation that commonly occurs when dealing with bacteria from diverse and poorly studied habitats (Hauxhurst et al., 1980). 
Table 2. Differential characteristics of the nine phenons of moderately halophilic Gram-negative bacteria

\begin{tabular}{|c|c|c|c|c|c|c|c|c|c|}
\hline $\begin{array}{r}\text { Phenon } \ldots \\
\text { No. of strains } \ldots\end{array}$ & $\begin{array}{l}\text { A } \\
18\end{array}$ & $\begin{array}{l}\text { B } \\
7\end{array}$ & $\begin{array}{l}\mathrm{C} \\
5\end{array}$ & $\begin{array}{l}\mathrm{D} \\
8\end{array}$ & $\begin{array}{l}E \\
10\end{array}$ & $\begin{array}{l}F \\
18\end{array}$ & $\begin{array}{l}\mathrm{G} \\
18\end{array}$ & $\begin{array}{r}\mathrm{H} \\
4\end{array}$ & $\begin{array}{l}\text { I } \\
3\end{array}$ \\
\hline Oxidase production & - & - & - & + & + & + & + & + & + \\
\hline Anaerobic growth & - & - & - & - & - & + & + & + & + \\
\hline Nitrate reduction & $(-)$ & + & - & + & + & - & - & - & - \\
\hline Nitrite reduction & - & - & - & + & + & - & - & - & - \\
\hline $\mathrm{O} / \mathrm{F}$ (glucose) & $\mathrm{o}$ & 0 & o & -10 & $\mathrm{o}$ & $\mathrm{F}$ & $\mathbf{F}$ & $\mathbf{F}$ & $\mathbf{F}$ \\
\hline Gelatin hydrolysis & - & - & - & - & - & + & + & + & + \\
\hline Tween hydrolysis & d & - & - & $(-)$ & - & - & + & + & + \\
\hline DNAase production & - & - & - & - & - & + & + & + & + \\
\hline Voges-Proskauer & - & - & - & - & - & + & + & + & + \\
\hline \multicolumn{10}{|l|}{ Utilization of: } \\
\hline D-Galactose & + & + & + & - & - & d & - & + & $\mathrm{d}$ \\
\hline D-Manose & + & + & + & - & + & $(-)$ & d & $\mathrm{d}$ & d \\
\hline Trehalose & + & $\mathrm{d}$ & - & - & + & $(+)$ & + & d & d \\
\hline Sucrose & + & + & $(-)$ & - & + & $\mathrm{d}$ & $(+)$ & - & d \\
\hline Adonitol & $\mathrm{d}$ & + & - & - & - & - & - & - & 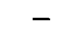 \\
\hline Dulcitol & $(-)$ & + & + & - & - & - & - & - & - \\
\hline Benzoate & $(-)$ & + & - & - & - & - & - & - & - \\
\hline Citrate & + & + & + & + & + & d & d & + & - \\
\hline L-Leucine & d & - & - & + & + & - & - & - & 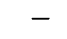 \\
\hline
\end{tabular}

+ , positive reaction; - , negative reaction; $\mathrm{d}, 21-79 \%$ strains positive. Parentheses indicate that at least $80 \%$ of the strains gave the result indicated. $\mathrm{O}$, oxidative; $\mathrm{F}$, fermentative.

With respect to the genera represented in our cluster analysis, the representatives of Vibrio were by far the most abundant, followed by Flavobacterium and, with much lower numbers, Alteromonas, Alcaligenes and the Chromobacterium-type group. In marine habitats high proportions of Vibrio species have been found in many different studies (Kaneko \& Colwell, 1974; Kaneko et al., 1979; Lovelace et al., 1967). However, Alteromonas, which is a very common inhabitant of this environment (Baumann et al., 1972; Gauthier et al., 1975), did not comprise a large proportion in our case.

The organisms that did not cluster could not be identified, with the exception of strains A-37 and A-52, which were short non-motile rods, strict aerobes, catalase positive and oxidase negative and can be assigned to the genus Acinetobacter. Flavobacterium halmephilum CCM 2833, used as a reference strain, was also recovered outside the major clusters, indicating that this organism, isolated from the Dead Sea, is represented poorly, if at all, in the saltern studied. Although the Dead Sea is hypersaline environment it belongs to the so-called athalassohaline waters that have proportions of salts very different from seawater; therefore important differences in the composition of the microbial population might be expected.

It has been proposed that moderate halophiles might have originated from marine bacteria by relatively simple evolutionary adaptive processes (Forsyth et al., 1971). The groups of moderate halophiles that we have found are related to well-known inhabitants of marine environments, but further studies are required to ascertain their taxonomic relationships.

The authors are indebted to the Gulbenkian Institute of Science (Oeiras, Portugal) for the use of its computer and facilities. We are grateful to Drs M. E. Rhodes-Roberts, R. R. Sokal, M. Kocur, A. Vila, J. Sancho and J. Tamames for their valuable advice and discussion.

\section{REFERENCES}

BaIN, N. \& SHEwaN, J. M. (1968). Identification of Aeromonas, Vibrio and related organisms. In Identification Methods for Microbiologists, part B, pp. 79-84. Edited by B. M. Gibbs \& D. A. Shapton. London: Academic Press.
Baumann, L., Baumann, P., Mandel, M. \& Allen, R. D. (1972). Taxonomy of aerobic marine eubacteria. Journal of Bacteriology 110, 402-429.

Brock, T. D. (1979). Ecology of saline lakes. In Strategies of Microbial Life in Extreme Environments. pp. 
29-47. Edited by M. Shilo. Weinheim: Verlag Chemie.

Buchanan, R. E. \& Gibbons, N. E. (editörs) (1974). Bergey's Manual of Determinative Bacteriology, 8th edn. Baltimore: Williams \& Wilkins.

Christensen, W. B. (1946). Urea decomposition as a means of differentiating Proteus and paracolon cultures from each other and from Salmonella and Shigella. Journal of Bacteriology 52, 461-466.

CoWAN, S. T. \& StEel, K. J. (1974). Manual for the Identification of Medical Bacteria. Cambridge : Cambridge University Press.

DE LEY, J., SEgers, P. \& Gillis, M. (1978). Intra- and intergeneric similarities of Chromobacterium and Janthinobacterium ribosomal ribonucleic acid cistrons. International Journal of Systematic Bacteriology 28, 154-168.

Dussault, H. P. (1955). An improved technique for staining red-halophilic bacteria. Journal of Bacteriology 70, 484-485.

ElAZARI-VOLCANI, B. (1940). Studies on the microflora of the Dead Sea. Ph.D. thesis, Hebrew University, Jerusalem.

ForsYTh, M. P., Shindler, D. B., Gochnauer, M. B. \& KUSHNER, D. J. (1971). Salt tolerance of intertidal marine bacteria. Canadian Journal of Microbiology 17, 825-828.

Frazier, W. C. (1926). A method for the detection of changes in gelatin due to bacteria. Journal of Infectious Diseases 39, 302-309.

Gauthier, M. J., Shewan, J. M., Gibson, D. M. \& LEE, J. V. (1975). Taxonomic position and seasonal variations in marine neritic environment of some Gram-negative antibiotic-producing bacteria. Journal of General Microbiology 87, 211-218.

HauXhurst, J. D., KRICheVSKY, M. I. \& Atlas, R. M. (1980). Numerical taxonomy of bacteria from the gulf of Alaska. Journal of General Microbiology 120, 131-148.

Holmes, B. \& Owen, R. J. (1979). Proposal that Flavobacterium breve be substituted as the type species of the genus in place of Flavobacterium aquatile and emended description of the genus Flavobacterium: status of the named species of Flavobacterium. International Journal of Systematic Bacteriology 29, 416426.

JACCARD, P. (1908). Nouvelles recherches sur la distribution florale. Bulletin de la Société vaudoise des sciences naturelles 44, 223-270.

JefFries, C. D., Holtman, D. F. \& Guse, D. G. (1957). Rapid method for determining the activity of microorganisms on nucleic acids. Journal of Bacteriology 73, 590-591.

KANEKo, T. \& COLWELl, R. R. (1974). Distribution of Vibrio parahaemolyticus and related organisms in the Atlantic Ocean off South Carolina and Georgia. Applied Microbiology 28, 1009-1017.

Kaneko, T., KRIChevsky, M. I. \& Atlas, R. M. (1979). Numerical taxonomy of bacteria from the Beaufort Sea. Journal of General Microbiology 110, 111-125.
Kovacs, N. (1928). Eine vereinfachte Methode zum Nachweis der Indolbildung durch Bakterien. Zeitschrift für Immunitätsforschung und experimentelle Therapie 55, 311-316.

Kovacs, N. (1956). Identification of Pseudomonas pyocyanea by the oxidase reaction. Nature, London 178, 703.

KUSHNER, D. J. (1978). Life in high salt and solute concentrations: halophilic bacteria. In Microbial Life in Extreme Environments. pp. 317-368. Edited by D. J. Kushner. London: Academic Press.

LARSEN, H. (1962). Halophilism. In The Bacteria, vol. IV, pp. 297-336. Edited by I. C. Gunsalus \& R. Y. Stanier. London: Academic Press.

LEIFSON, E. (1963). Determination of carbohydrate metabolism of marine bacteria. Journal of Bacteria 85, 1183-1184.

Lovelace, T. E., Tubiash, H. \& Colwell, R. R. (1967). Quantitative and qualitative commensal bacterial flora of Crassostrea virginica in Chesapeake Bay. Proceedings of the National Shellfisheries Association 58, 82-87.

MERKEL, J. R. (1972). Influence of salts on the vibriostatic action of 2,4-diamino-6,7-diisopropyl pteridine. Archiv für Mikrobiologie 81, 379-382.

RHODEs, M. E. (1958). The cytology of Pseudomonas spp. as revealed by a silver-plating staining method. Journal of General Microbiology 18, 639-648.

RODRIGUEZ-VALERA, F., RUIZ-BERRAQUERo, F. \& RAMOS-CORMENZANA, A. (1980). Isolation of extremely halophilic bacteria able to grow in defined inorganic media with single carbon sources. Journal of General Microbiology 119, 535-538.

Rodriguez-Valera, F., Ruiz-Berraquero, F. \& Ramos-Cormenzana, A. (1981). Characteristics of the heterotrophic bacterial populations in hypersaline environments of different salt concentrations. Microbial Ecology 7, 235-243.

SIERRA, G. (1957). A simple method for the detection of lipolytic activity of microorganisms and some observations on the influence of the contact between cells and fatty substrates. Antonie van Leeuwenhoek 23, 15-22.

SKERMAN, V. B. D. (1967). A Guide to the Identification of the genera of Bacteria. 2nd edn. Baltimore: Williams \& Wilkins.

SKeRMan, V. B. D., MCGowan, V. \& SNEATH, P. H. A. (1980). Approved lists of bacterial names. International Journal of Systematic Bacteriology 30, 225420.

SNEATH, P. H. A. (1974). Genus Chromobacterium Bergonzini 1881. In Bergey's Manual of Determinative Bacteriology, 8th edn, pp. 354-357. Edited by R. E. Buchanan \& N. E. Gibbons. Baltimore: Williams \& Wilkins.

SNEATH, P. H. A. \& SoKal, R. R. (1973). Numerical Taxonomy. The Principles and Practice of Numerical Classification. San Francisco: W. H. Freeman. 